\title{
A New Golden Age for Newspaper Research
}

\author{
Helmer Helmers
}

In May 2017, scholars of Dutch and Flemish media history gathered at the University of Amsterdam to celebrate the appearance of Arthur der Weduwen's bibliography of early Netherlandish newspapers: Dutch and Flemish Newspapers of the Seventeenth Century. ${ }^{1}$ It should not be surprising that this event caused considerable excitement amongst those present. In two massive folio volumes, Dutch and Flemish Newspapers lists all the surviving issues of newspapers that appeared between 1618 and 1700, many of which had been unknown before. It also includes a hefty introduction on Low Countries newspaper history, and a range of shorter, introductory essays on every single newspaper title known to have been published in the period. Greatly extending the foundational work by the Swedish scholar Folke Dahl, whose bibliography of Dutch corantos had been the standard reference work for decades, Der Weduwen's seminal piece of scholarship transformed the field, heralding a new age of newspaper research.

The essays assembled in this issue of Early Modern Low Countries are the product of that celebratory meeting. While the contributing authors could not yet fully profit from the new bibliography, they exemplify that the history of news in the Low Countries is still very much work in progress, and are providing a taste of the kind of work that can be expected in the near future. Indeed, the significance of Der Weduwen's book is not only the wealth of information it offers on the earliest Dutch-language newspapers, but also that it is a huge impetus to new research on Low Countries as well as European press history. Much of that development, dependent as it is on international collaboration and digitization projects, can be confidently predicted. Yet the new bibliography also shows us that in the case of the Low Countries press history, basic discoveries based on painstaking archival research can still be made. Thus Der Weduwen was the first to prove the existence of a newspaper in Utrecht as early 1623 , thirty-five years earlier than had previously been thought, through a discovery in the municipal archives of Deventer. ${ }^{2}$

1 Der Weduwen, Dutch and Flemish Newspapers.

2 Der Weduwen, 'Utrecht's First Newspaper'; Der Weduwen, Dutch and Flemish Newspapers, 423-425.

DOI 10.18352/emlc.58 - URL: http://www.emlc-journal.org

Publisher: Stichting EMLC, supported by Utrecht University Library Open Access Journals | The Netherlands Copyright: The Author(s). This work is licensed under a Creative Commons Attribution-NonCommercial 4.0 International License. 
Many more such exciting discoveries may still be made, and the most revealing ones are as likely to be made in archives outside the Low Countries as in those within. Like Folke Dahl, Der Weduwen has already combed various foreign archives for issues of corantos that were sent abroad to foreign subscribers, but we cannot tell what kind of information on Dutch newspapers archives throughout Europe may still yield. Shortly after the appearance of the bibliography, Der Weduwen himself encountered a remarkable source in the Royal Library in Copenhagen. In an early catalogue, he found a reference to an issue of Broer Jansz's Tydinghen uyt verscheyde Quartieren dated December 1618. This suggests that the first known issue of this important newspaper appeared months earlier than previously known. It may well be that the first Dutch-language newspaper ever to be published still lies undiscovered in a little-known archive. Will we some day have to push back the arrival of periodical press in the Low Countries with months or even years? With more research to come, aided by digital tools, the history of the news thus continues to be rewritten. This introduction aims to sketch why that work is so important, and in which directions the field might develop in future years.

\section{The Arrival of the Newspaper in the Low Countries}

It is only fitting that this special issue appears in 2018, the 400-year anniversary of the newspaper in the Low Countries. On 14 June 1618, Caspar van Hilten published the first known issue of the Courante uyt Italien, Duytschlandt, etc. It was a seemingly unimpressive piece of work: a single sheet, densely printed in black letters with disparate news reports on faraway conflicts. Yet despite the humble appearance of the first newspapers, historians of the press have traditionally seen the introduction of the printed periodical press in the seventeenth century as one of the most consequential events in media history. For the first time, a wider audience gained access to a regular stream of news of the kind that hitherto had been accessible only to elite readers such as diplomats, magistrates, and rich merchants who could afford manuscript newsletters. While the first newspapers printed mostly foreign news, historians have hailed the arrival of the medium as a democratization of political information. Cheap, periodically printed news allowed a wide audience to form, and later also express, an educated opinion on the news. Following Jürgen Habermas, many have therefore considered access to news and newspapers a constitutional element of a developing public sphere. ${ }^{3}$

Whether or not one accepts this narrative (it has been much debated in recent years), scholars agree that the Low Countries played a crucial role in the development of the early modern press. The United Provinces and the Spanish Netherlands were certainly not the first countries to introduce newspapers. The first periodically printed sheets of news appeared in the Holy Roman Empire in the early seventeenth century, first in Strasbourg, in 1605, and later in Wolfenbüttel (1609) and Frankfurt (1615). It was only in June 1618, it seems, that the first Dutch printed news periodical started to appear on a weekly basis in 
Amsterdam, Caspar van Hilten's Courante uyt Italien, Duytslandt, \&c, which was followed soon afterwards by Broer Jansz' Tydinghen uyt verscheyde Quartieren. Filled with news on foreign wars and based on foreign sources, they made a huge impact, and soon catered to a wide clientele in the United Provinces and beyond. In the Spanish Netherlands, Abraham Verhoeven's Nieuwe Tijdinghen followed suit, providing counter-narratives to the news appearing in the Northern papers. From its earliest days, the development of the press owed much to international exchange and competition. Both Dutch and foreign-language newspapers printed in the Low Countries circulated widely, even globally, and this is exactly why we find so many newspapers in foreign archives. ${ }^{4}$

Although German publishers can be credited with the invention of the newspaper, publishers in the Low Countries made their mark as innovators. The Amsterdam newspapers by Van Hilten and his competitor Broer Jansz revolutionized the news trade in more than one aspect. Firstly, they introduced a cost-effective design that would dominate Dutch newspapers in the following century and would soon be imitated abroad: two densely printed black-letter columns prioritized efficiency over looks, which greatly helped to sustain the new medium. Another Amsterdam innovation which helped to undergird the financial sustainability of the medium was the introduction - soon after first known newspaper appeared - of the advertisement. This, and a healthy domestic market, allowed Northern publishers to develop into major European players. ${ }^{5}$

In the Southern Netherlands, the situation was markedly different, because strict government control limited entrepreneurial options. Abraham Verhoeven's Nieuwe Tijdinghen was at least in part the mouthpiece of the Brussels government, and Verhoeven had to tread carefully so as not to alienate himself from the censor. Yet the Nieuwe Tijdinghen was a spectacular venture nonetheless. It was unique both in the frequency with which it appeared - Verhoeven published 196 issues in the year 1621 alone, far more than the mere 52 issues published by his Northern competitors - and in its pamphlet-like appearance. Complete with illustrations and with more emphasis on opinion-making, Verhoeven' Nieuwe Tijdinghen looked more like a modern newspaper than the competing titles in the Dutch Republic. ${ }^{6}$

\section{The Old and the New Press History of the Low Countries}

Despite the crucial role of the Low Countries in European press history, research into the history of the Dutch-language newspaper has developed haphazardly. It is significant that the first major works on seventeenth-century Dutch-language newspapers, by Sautijn Kluit (1866-1883), Goovaerts (1881) Stolp (1938) and foremost the internationally read Folke Dahl (1939 and 1946) are still regularly cited today. ${ }^{7}$ The long time lag between the

4 See e.g. Maier, 'Zeventiende-eeuwse Nederlandse kranten'.

5 See the article by Andrew Pettegree and Arthur der Weduwen in this issue, as well as their forthcoming book, The Bookshop of the World. Making and Trading Books in the Dutch Golden Age (Yale University Press, 2019).

6 Arblaster, From Ghent to Aix.

7 Sautijn Kluit, 'De Haarlemsche Courant'; Goovaerts, Abraham Verhoeven; Stolp, De eerste couranten; Dahl, Amsterdam, earliest newspaper centre; Dahl, Dutch Corantos 1618-1650. 
bibliographies of Dahl and Der Weduwen is not only testimony to the great quality of the old history of the press, it is also an indication that the increased access to the archives in Eastern Europe and digitization projects, including online catalogues and the digitization of archives, have completely revolutionized the field, and provided the means that were necessary to surpass the formerly unrivalled comprehensiveness of the likes of Dahl.

The greatest limitation of previous histories of the seventeenth-century press in the Low Countries is undoubtedly their national focus. While, as we have seen, the early modern newspaper business was inherently international because of the news networks on which it depended, the news stories that were printed, and its circulation in circles of merchants and diplomats, the history of this important phenomenon has been written from a strictly national perspective. Only in recent years has a new generation of scholars, including Paul Arblaster, Michiel van Groesen, Joop Koopmans, Otto Lankhorst and Ingrid Maier, adopted more inter- and transnational perspectives. Arblaster's From Ghent to Aix, for instance, pays considerable attention to the relationship between Verhoeven and his competitors in the Northern Low Countries. ${ }^{8}$ Michiel van Groesen's project on Atlantic news shifts our attention to the circulation of news in the global networks of early modern Low Countries imperialism. ${ }^{9}$ Despite much inspiring new work in this area, the international approach to news circulation has only just begun. Joad Raymond's collaborative project on European News Networks, which studied the networks through which the news travelled before it entered into print, was far from exhaustive. ${ }^{10}$ A much bigger, international project is required for us to fully comprehend the European connectedness of the news business in terms of the translation, circulation, and adaptation of the news itself as well as the cooperation and imitation between news producers in various countries.

While transnational approaches often foreground a network that is relatively independent of individuals, if we are to transcend (national) case studies, research in the coming years will also have to focus on state agents who sought to manage the new medium of the newspaper. Indeed, a considerable body of recent work has explored the attempts by early modern states to control the news, both inside and outside their territories. ${ }^{11}$ The pendulum of scholarly opinion on the relationship between power and print seems to be swinging away from the more positive Habermasian appraisal of the early modern public sphere, emphasizing more and more the extent to which the media were controlled and manipulated by those in power - even in the Dutch Republic, where the most illicit and controversial material was printed. It will be exciting to see how this continuing and fruitful line of research can be squared with the transnational network research that is conducted at the same time.

A third aspect that will continue to be addressed by future scholars of the newspaper concerns the economy of news. What was the business model of the early modern news

8 Arblaster, From Ghent to Aix.

9 Van Groesen, Amsterdam's Atlantic; Van Groesen, '(No) News from the Western Front'.

10 Raymond and Moxham, News Networks .

11 See for instance the 2016 issue of Media History (22:1-2), devoted to the management of news, with articles by Jason Peacey, Stéphane Haffemayer and myself on this topic. The recent Annual Book Conference in St Andrews (June 2018) was fully devoted to the relationship between print and power. 
publisher, and how did it evolve? The Dutch and Flemish context shows thriving moguls avant la lettre, such as Abraham Casteleyn, competing with struggling newspapermen who could barely support their family. Abraham Verhoeven, as Steven Van Impe shows in this issue, went from relative wealth to poverty. We still know very little about the newspaper publisher's clientele and their employees, and about the general workings of the successful and the unsuccessful newspaper businesses as the trade evolved in the seventeenth century.

The articles in this issue address all three themes outlined above, although they privilege the transnational and economic aspects of the newspaper. The articles by Esther Baakman, Tiffany Bousard and Jan Hillgaertner explore the relationship between Low Countries newspapers and the wider world. The articles by Baakman and Bousard are part of Van Groesen's Leiden project mentioned above. After Van Groesen's own pioneering work on Atlantic news, Baakman and Bousard are the first to consider how news from the all-important Atlantic arena circulated and shaped opinions in the Dutch Republic (Baakman) and the Spanish Netherlands (Bousard). In her article, Baakman studies how the Berbice slave revolt (1763) was reported in the Northern Netherlands, and how such reports affected Dutch opinion on slavery. Bousard examines how two newsmen from the Southern Low Countries, Abraham Verhoeven and Pierre Hugonet, dealt with adverse news from the Atlantic, a delicate task in a government-controlled environment. Jan Hillgaertner, who works on a $\mathrm{PhD}$ project on the German newspaper in the seventeenth century, asks the novel question of how the German newspapers were affected by those in the Dutch Republic. While each of these articles adopts a different international perspective on the newspapers in the Low Countries, all three authors are clearly concerned with the same question, namely how the traditional national press history should be rethought in a global age.

The economy of the newspaper connects the other three articles, by Der Weduwen, Pettegree and Der Weduwen, and Van Impe. Arthur der Weduwen's contribution addresses the difficult question of how we should understand the Dutch news market as a system that on the one hand produced a staggering diversity of titles, which, on the other hand, all looked pretty much the same. According to Der Weduwen, however, a careful reading of the material shows that customers had plenty of choice. Pettegree and Der Weduwen discuss what is probably the most important Dutch innovation in the history of the newspaper: the advertisement, which helped the early newspaper to survive economically. By examining a wide range of adverts in the earliest Dutch newspapers, they show what historians might learn from these seemingly innocuous texts. Van Impe, finally, delves into the account books of the newspapermen in the Southern Low Countries. How could a publisher of cheap news make a profit? In the age of digital newspapers, this, perhaps, is the most topical question of all.

\section{Bibliography}

Arblaster, Paul, From Ghent to Aix. How They Brough the News in the Habsburg Netherlands (Leiden 2014).

Dahl, Folke, Amsterdam, earliest newspaper centre of western Europe: New contributions to the history of the first Dutch and French corantos (The Hague 1939). 
Dahl, Folke, Dutch Corantos 1618-1650. A Bibliography (The Hague 1946).

Goovaerts, Alfons, Abraham Verhoeven van Antwerpen, de eerste gazettier van Europa. Bio-bibliographische studie (Antwerpen 1881).

Groesen, Michiel van, Amsterdam's Atlantic. Print Culture and the Making of Dutch Brazil (Philadelphia 2017).

Groesen, Michiel van, '(No) News from the Western Front: The Weekly Press of the Low Countries and the Making of Atlantic News'. The Sixteenth Century Journal 44 (2013/3), 739-760.

Habermas, Jürgen, The Structural Transformation of the Public Sphere. An Inquiry into a Category of Bourgeois Society (Cambridge MA 1989).

Maier, Ingrid, 'Zeventiende-eeuwse Nederlandse kranten vertaald voor de Tsaar'. Tijdschrift voor Mediageschiedenis 12 (2009), 27-49.

Raymond, Joad and Noah Moxham (eds.) News Networks in Early Modern Europe (Leiden 2017).

Sautijn Kluit, W.P., 'De Haarlemsche Courant'. Jaarboek van de Maatschappij der Nederlandse Letterkunde (1873), 3-131.

Stolp, Annie, De eerste couranten in Holland. Bijdrage geschreven tot de geschiedenis der geschreven nieuwstijdingen (Haarlem 1938).

Weduwen, Arthur der, 'Utrecht's First Newspaper Rediscovered. Adriaen Leenaertsz and the Nieuwe courante uyt Italien, Duytslandt ende Nederlant (1623)'. Quaerendo 46 (2016/1), 1-19.

Weduwen, Arthur der, Dutch and Flemish Newspapers of the Seventeenth Century, 1618-1700, 2 vols. (Leiden 2017). 